\title{
MOTHER AND NEWBORN HOME CARE EDUCATION PROGRAM THE EFFECTS OF "MOTHER AND NEWBORN HOME CARE EDUCATION PROGRAM (MNHCEP)" ON MOTHER AND PERSONS PROVIDING CARE OF MOTHER/NEWBORN
}

\author{
Esin ÇEBER Neriman SOĞUKPINAR Birsen KARACA SAYDAM Rabia EKTi GENÇ \\ Hafize ÖZTÜRK CAN Zehra BAYKAL AKMEŞE Gülsün ÖZENTÜRK
}

Ege University Izmir Atatürk School Of Health, Bornova, Izmir, Turkey

Yazıșma Adresi:

Zehra Baykal AKMEŞE

Ege Üniversitesi İzmir Atatük Sağlık Yüksekokulu, Ege Üniversitesi Tıp Fakültesi Kampüsü, Bornova 35100 İzmir - Türkiye

E posta: zehra.baykal@ege.edu.tr

Kabul Tarihi: 27 Mart 2013

Balıkesir Sağıık Bilimleri Dergisi

ISSN: 2146-9601

e-ISSN: 2147-2238

bsbd@balikesir.edu.tr www.bau-sbdergisi.com

\section{ÖZET}

AMAÇ: Bu çalışmanın amacı; ebeler tarafından gerçekleştirilen bir eğitim programı olan Anne ve Yenidoğan Evde-Bakım eğitiminin, anneler ve annenin/yenidoğanın doğumundan sonra evde bakımını üstlenen kişiler üzerindeki etkilerini değerlendirmektir.

YÖNTEMLER: Çalışma, Türkiye' nin metropol kentlerinden İzmir' deki bütün özel hastanelerinde yürütüldü. Çalışma verileri, annenin/yenidoğanın sorumluluğunu ve bakımını üstlenen kişilerden (183) ve annelerden (297) elde edildi. Eğitimleri verecek olan ebelere interaktif eğitim yöntemleri ile uygulamalı eğitim verildi ve loğusalık döneminde dört defa ziyaret gerçekleştirildi. Anne ve yenidoğanın bakımından sorumlu olan aile bireylerinin mevcut bilgilerinin belirlenmesi amacıyla, ilk aşamada, kendilerinin ve bebeklerinin bakımı ile ilgili bilgilerini ölçen bir ön-test uygulandı.

BULGULAR: Çalışmanın sonucunda elde edilen bulgular, bakımı üstlenen, anne ve bakımından sorumlu olan kişilerin bilgi ve uygulamalarında farklılık yaratılması ve bu farklılık süresince, hizmet görenlerin memnuniyet seviyelerinin yüksek olması, projenin hedeflerinin gerçekleştirildiğini göstermesi bakımından önemlidir.

SONUÇ: Loğusa döneminde, annelere ve yenidoğanlara verilen sağlık hizmetinin kalitesi eğitimle desteklendiğinde, sağlık durumları gelecekte bundan olumlu bir şekilde etkilenecektir.

Anahtar Kelimeler: Evde bakım, Eğitim, Ebeler, Loğusa, Yenidoğan

\section{SUMMARY}

OBJECTIVE: The aim of the study was evaluate the effects of an education program about Mother and Newborn Home Care by midwives, on mothers and person providing care of mother/newborn in the home after childbirth.

METHOD: The study was conducted in all private hospitals in Izmir Metropolis in Turkey. Study data were collected through person providing care responsible for the care of mother/newborn (183), mothers (297). Midwives who will give the trainings were given applied education by interactive education methods were visited four times in postpartum period. In order to determine the present knowledge of family members responsible for the care of mother and baby at first degree a pre test analyzing their knowledge's about care of them and their babies was applied.

FINDINGS: Findings as a result of the study, causing change in application and knowledge of person providing care responsible persons for care and mother and during this change satisfaction levels of those receiving service being high is important in indicating that the goals of the project was realized.

RESULT: During postpartum period, when the quality of the health care for mothers and newborns is supported with education, their health status will be affected positively in future.

Key words: Home care, Education, Midwives, Postpartum, Newborn 


\section{INTRODUCTION}

Maternal mortality and neonatal deaths are important health problems across the globe, especially in developing countries. ${ }^{1-4}$ Half of the postpartum deaths occurs on the first day of births, $80 \%$ of deaths occur within two days after birth. ${ }^{5}$ Maternal deaths, $28.5 \pm 2.5$ in 100.000 births, occur because of postpartum obstetric bleeding and eclampsia in Turkey. ${ }^{6}$ Also neonatal mortality rates are high, this rate is reported to be $13 / 1000 .^{7}$

Postpartum visits in many developing countries are after first six weeks and made by midwifes. ${ }^{5}$ National guidelines recommend at least two follow-up consultations, one of which should be the first day after delivery, during the postpartum period. ${ }^{8}$ Unfortunately, postpartum follow-up has not been comprehensive in the first days postpartum for a number of reasons in Turkey. ${ }^{9}$ However, the risks for mothers and newborns reduce in this period. The important thing is that the care is taken within the first six weeks. Postpartum health care services are included in the mother and baby health care services in terms of our country's health policy. ${ }^{1}$ The quality of health care service is as important as the health care service itself. The quality of the health care service given by the family members at home is as important as the health care service given by medical personnel. However, there is not enough knowledge about postpartum health care service in Turkey. ${ }^{1}$

Maternal and neonatal mortality resulted from the lack of pregnancy, birth and postpartum health care services is aimed to be diminished $75 \%$ by 2015 across the globe. ${ }^{3,4}$ Postpartum home care visits of midwifes to give education about mother and newborn is an initiative to decrease mother-newborn morbidity and mortality. ${ }^{10}$ The education studies show that health problems decreased and people became content. $^{11,12}$ It is important that midwifes having a bachelor's degree give education for mother and newborns. Midwifery education at tertiary level was still struggling to find a way to establish a universally accepted curriculum and gain a recognized Status. In1997, based on the decision by the Turkish Parliament. ${ }^{13}$ Graduate education started 4-year degree programs leading to a BSc in midwifery to follow 11 years of formal schooling, including secondary education. The development is of paramount importance, as it constitutes the initial implementation of the harmonization process with the European Union and setting standards to attain desired outcomes in the profession of Midwifery. Today, co-operation between the EU universities and their Turkish counterparts offer university students and academics various exchange program. ${ }^{14}$

In Turkey, the length of stay in hospital for postpartum mothers who experience uncomplicated vaginal births has decreased progressively during recent years. The trend towards increasingly shorter hospital stays has raised concerns about the potential consequences of reducing the length of time in which necessary care can be delivered to newborns and their mothers in hospital. Although routine lengths of stay after uncomplicated childbirth have been 24 hrs for many years, the available evidence suggests that most mothers and babies who stay in hospital for a short period do not receive early follow-up. In the absence of definitive data on the length of postpartum stay, current standards for discharge have been issued by hospitals. ${ }^{15}$

The home care visits of midwifes and midwifery education are very important for pregnancy, birth and postpartum mother and baby health. During home visits, when midwifes give education to mother and the persons providing care of mother/newborn individuals (grandmother, sister etc.) the quality of health care service increases. When the attempts such as breastfeeding, umbilical cord care, newborn bath, and clothing are made with parents, it will increase the quality of the education. The important element is that the participants become more active within the scope of this education. Learners, examiners, interpreters, participants, are accepted to active learning process. Focusing on learners before subjects is a more realistic attempt in an active learning. ${ }^{16,17}$

The aim of the study was evaluate the effects of an education program about Mother and Newborn Home Care (MNHC) by midwives, on mothers and person providing care of mother/newborn in the home after childbirth.

\section{MATERIAL AND METHODS Study design}

A pre-test and post-test design was applied to evaluate the effects of Mother and Newborn Home Care 
Education Program (MNHCEP) by midwives on mothers and person providing care of mother/newborn.

\section{Sample and data collection process}

The study process was given flow chart (Figure 1). At the beginning of the program, in the first one month period of the study Education Program was prepared by teaching staff. Three midwives volunteered to be a trainer and they were trained in a two-week trainers' training program. Topics covered in the trainers' training program were adult learning principles, creating a positive climate, clinical demonstration, coaching and effective use of audiovisual materials. The two week part of the training of the trainers program (first week) included also the standard MNHCEP (second week).

After completion of education of trainer midwives introduction of MNHCEP was done at the hospitals included in the study by Izmir Health Institutions Association Organization and volunteer mothers person providing care of mother/newborn were started to be included in the project.

The study was conducted between April-December 2006 dates in Izmir Metropolis in Turkey. All births (4734) in all private hospitals in Izmir have constituted the universe of research by the study stratified sampling. Inclusion criteria for the study were first and normal delivery; normal newborn, and willingness to participate the study (1300). The sample size was determined 297 using statically software (statcalc), with standard error 0.05, confidence level was 95\%. Then all samples were selected using random sampling. Selected mothers bearing between these dates in these hospitals the aim of the study was explained and the study was continued with mothers volunteered to participate in the study. Study data were collected mothers (297). Also, questionnaire forms were used to the person (183) living and providing care of mother/newborn at the time of the all visits.

Mothers and newborns after birth by three midwives were visited at home four times (on 2, 9, 24, and 40, day's afterbirth), every visit lasted 120 minutes. Pre-test was applied in the first visit. Mothers and person providing care of mother/newborn to participate in the study and to receive MNHCEP by the midwives that have taken trainer training. Mothers and providing care of mother/newborn have received trainings about MNHC at home from trainer midwives, during at the visits. At the visits and education sections were used along with demonstration and coaching techniques by midwives. Post-test was applied in last visit after the end of MNHCEP in last visit (Figure 1).

Figure 1: MNHCEP Study Procedure

Preparation of "Maternity and Newborn Care Education" Program.

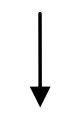

Trainer Education on "Maternity and Newborn Care" to selected midwives for two weeks.

Introduction of "MNHCEP" at the hospitals included in the study.

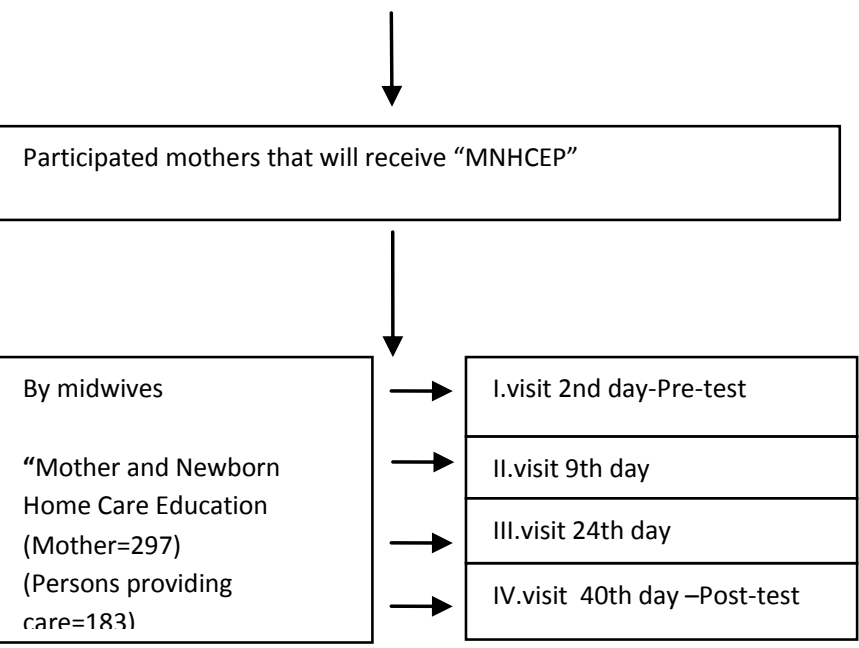

Instruments:

Socio-demographics information for mothers and persons providing care of mother/newborn; it is a form consisting 16 questions to determine the characteristics of obstetrics histories and family socio-demographics information of mothers and persons providing care of mother/newborn participated in the study.

Pre- and Post-test; both of the questionnaires, including the same questions and the statements, were designed to assess the MNHC knowledge of midwives about the $\mathrm{MNHC}$. Besides, both of the questionnaires, including the 
same questions and the statements, were designed to assess the MNHC knowledge of mothers and persons providing care of mother/newborn about the MNHC.

The questionnaire items were developed by reviewing the literature and by drawing upon the researchers' experiences. Some of the statements were correct while some others were incorrect. Correct responses were summed and converted to 120 to obtain the MNHC knowledge score.

\section{Data collection and measurements}

Study data were collected using face to face interview technique with mothers and persons providing care of mother/newborn (grandmother, father, aunt and other) during home visits by trained midwives. The questionnaire form was completed 15 minutes.

\section{Data analyses}

Statistical analysis was performed using the computer software SPSS 11.0 for Windows. Entry of data was done by trainers that have given the trainings of trainer midwives. Trainer midwives not taking part in the coding of data has provided data to be coded without being exposed to bias and blinding process was realized in the study. Initial analysis included frequency and percentages of categorical data means, medians, and standard deviations (SDs) of continuous variables. In comparison of difference between pre and post knowledge score levels of mothers and persons was used Student $t$ test. Statistical significance required a $p$ value of $<0.05$ ).

\section{Ethical considerations}

The project was approved European Commission Project and Reproductive Health Program of Turkey. Ethics permission was given these committees. The participation was voluntary; verbal inform consent was taken each participant.

\section{RESULTS}

Two week of training was given to midwives that will carry out the postpartum care and training. The first week training was "Maternity and Newborn Care Training" in the second week "Training Skills Training" was given.
Findings about Mother and the Persons Providing Care of Mother/Newborn

When socio-demographical and introductory characteristics of mother participated in the study in the scope of "MNHCEP", project was analyzed.

In Table 1. Socio-demographical characteristics of mother and persons providing care of mother/newborn are seen. The average age of mothers is 29.91 \pm 3.89 (Min=21Max=42), $59.6 \%$ of them graduated from university, $57.6 \%$ of them work in any job and $95.3 \%$ of them have social security and 183 people were interviewed as the person providing care of mother/newborn in the family. It was determined that $88.5 \%$ of those people who will provide care are one of the family elders like grandmother. It was also determined that $83.6 \%$ of those people have experience about newborn and postpartum care before. When education levels of persons who will provide care for the newborn and women is analyzed it was determined that $59.6 \%$ of them left from primary school.

Also, it was determined that the average of number of pregnancies was $1.55 \pm .86$ (Min=1-Max=6), average of number of births was $1.25 \pm .49$ and average of number of miscarriages $(n=66) 1.37 \pm .73$. It was also determined that $92.3 \%$ of the women gave birth by cesarean.

In Table 2. Pre and post test average points of mothers and the persons providing care of mother/newborn are seen. According to that, a pre evaluation average point of mothers during the first visit was $94.0 \pm 13.8$, and an evaluation average point at the final visit was $119.8 \pm 2.3$. The persons providing care of mother/newborn of pretest average point was $89.6 \pm 15.3$, and post test average point was $119.0 \pm 4.4$. Average points of mother and persons providing care of mother/newborn from the pre and post test were found statistically significant $(p<0.05)$.

Age, educational background, pregnancy and number births of mothers were compared with averages of pre test, and post test average points of mothers and no statistically significant difference could be found between average test points $(p>0,05)$.

All of mothers and individuals providing care who say "knowledge, skills and attitude of the midwife came to visit was sufficient" and "I could benefit from the information given is 100 0\%. Mothers said that "their confidence increased with the trainings they received". 
Table 1. Socio-demographical characteristics of mother and persons providing care of mother/newborn

\begin{tabular}{|c|c|c|}
\hline Mother & $\mathrm{n}=\mathbf{2 9 7}$ & $\%$ \\
\hline $21-28$ age & 121 & 40,7 \\
\hline 29-36 age & 162 & 54,5 \\
\hline 37 age and up & 14 & 4,7 \\
\hline Average age of mothers & \multicolumn{2}{|c|}{$29.91 \pm 3.89(\operatorname{Min}=21-\operatorname{Max}=42)$} \\
\hline \multicolumn{3}{|l|}{ Education Levels } \\
\hline Primary school & 18 & 6,1 \\
\hline Secondary-high Scholl & 102 & 34,3 \\
\hline University & 177 & 59,6 \\
\hline \multicolumn{3}{|l|}{ Work } \\
\hline Yes & 171 & 57,6 \\
\hline No & 126 & 42,4 \\
\hline \multicolumn{3}{|l|}{ Social Security } \\
\hline Yes & 283 & 95,3 \\
\hline No & 14 & 4,7 \\
\hline $\begin{array}{l}\text { The Persons Providing Ca } \\
\text { Of Mother/Newborn }\end{array}$ & $n=183$ & $\%$ \\
\hline Father & 11 & 6,0 \\
\hline Grandmother & 162 & 88,5 \\
\hline Aunt & 4 & 2,2 \\
\hline Other & 6 & 3,3 \\
\hline \multicolumn{3}{|c|}{ Experience about newborn and postpartum care } \\
\hline Yes & 153 & 83,6 \\
\hline No & 30 & 16,4 \\
\hline \multicolumn{3}{|l|}{ Education Levels } \\
\hline Uneducated & 7 & 3,8 \\
\hline Primary school & 109 & 59,6 \\
\hline High School and up & 67 & 36,6 \\
\hline
\end{tabular}

and "they were satisfied in general to participate in this program". They could benefit and apply the information given, and were satisfied with the training given by midwife about mother and new-born

\section{DISCUSSION}

Newborn and postnatal mother death frequency is still an important problem in developing countries. It is known that along with insufficient health care, traditional applications peculiar to countries have also parts in these deaths.
The MNHCEP points of mothers and second persons giving care increase after midwifery education.

The objects of postpartum home care visits are to assess the health of the mother and newborn and give guidance and education to family. ${ }^{18}$ Face to face education given by medical personnel is one of the most influential education methods. ${ }^{19}$

Qilinvan et al. (2003) made a study that midwifery home visits and standard health care to reduce the problems in postpartum period with 139 adolescent. They determined that adolescent mothers getting home visits have more knowledge to reduce the problems about newborns. In addition to this, there is an increase in the knowledge of immunization, breastfeeding and lactation period.

Escobar et al. (2001) made a study to compare the home visits and the visits inside the hospital within the first 72 hours, and they found that although there is no difference between hospital and house visits in terms of clinical results, the mothers getting house visits are more content. In our study, both mother and persons providing care of mother/newborn giving health care service are very content during home visits as in other studies. ${ }^{12,13}$ When the individuals are content, education becomes more efficient. According to obstetrician Jean Ball (1982) studying about "Support theory of emotional goodness of mother"; woman needs support and education to be successful mother afterbirth. This success is influenced by knowledge and equipment of those who give support, quality of the support received increases satisfaction as well. $^{22}$

In their studies, Jansson (1985), Brown\&Johnson (1998), Williams\&Cooper (1992) and Malnory (1997) found that after postpartum early discharge, mothers and newborn getting health care services in houses have a lower hospitalization rate than the ones not getting health care service. Vittoz et al.(2004) found that postpartum 3-dayeducation program for mothers increases the lactation period. ${ }^{21,23-26}$

In postpartum period, mothers undergo important biopsycho-social changes. ${ }^{27}$ Mothers tend to adapt the changes in the postpartum period, take care of themselves and newborns. In this stressful period, when mothers are supported, their physical and mental health is affected positively. ${ }^{28}$ Social support to mothers in this period will prevent mothers from having psycho-social 
Table 2. Comparison of knowledge the level of mother and persons providing care of mother/newborn in pre and post test

\begin{tabular}{|c|c|c|c|c|c|c|}
\hline & Pre test & & Post test & & & \\
\hline & Mean, SD & Min-Max & Mean, SD & Min-Max & $\mathbf{t}$ & p \\
\hline Mother & $94,0 \pm 13,8$ & $40.0-120.0$ & $119,8 \pm 2,3$ & $80.0-120.0$ & 32.0 & 0.000 \\
\hline $\begin{array}{l}\text { Persons providing care of } \\
\text { mother/newborn }\end{array}$ & $89,6 \pm 15,3$ & $40.0-120.0$ & $119,0 \pm 4,4$ & $100.0-120.0$ & 7.9 & 0.000 \\
\hline
\end{tabular}

problems and affect both mother and newborn health positively.

Social support is a complex multidimensional phenomenon. While the greatest supporters of women were their mother's afterbirth in 1960s, to date the case has changed in favor of partner. ${ }^{20}$ In our culture, in the period after birth mother of woman or husband don't leave mother alone at least for the first twenty days or 40 days about. Usually grandmothers are greatest social supporters of mothers in Turkey. In our study, it is seen that it is mainly (88.5\%) grandmothers who give care for mother and newborns. Though traditional postnatal applications have decreased in metropolis, grandmothers may have the desire to carry on these applications. For this reason; a pre test analyzing knowledge about mother and newborn care was applied to determine present knowledge of grandmother staying with mother and same questions were repeated as post test at the last visit to analyze whether they resist to the trainings and to see if there is any part of education going wrong. Grandmother's post test average points being meaningfully higher than pre test average point $(89.6 \pm 15.3$ and $119.0 \pm 4.4)$ is important from the point they don't resist the training.

\section{CONCLUSION}

In this study which is a educational interference study with pre test post test application "Maternity and Newborn Home Care Training" was given to mothers and their relatives first degree responsible for the care of baby and mother included in the study by midwives who has taken special education about this subject.

In order to determine the present knowledge of family members responsible for the care of mother and baby at persons providing care of mother/newborn a pre test analyzing their knowledge, skills and attitudes about care of themselves and their babies was applied. After the analyses made it was determined that there is statistical increase in the points of family members responsible for the care and mother. It was also seen that satisfaction with the trainings given by midwives was also high level.

Findings as a result of the study, causing change in application and knowledge of persons providing care of mother/newborn responsible persons for care and mother and during this change satisfaction levels of those receiving service being high is important in indicating that the goals of the project was realized.

During postpartum period, when the quality of the health care for mothers and newborns is supported with education, their health status will be affected positively in future. The postpartum midwifery house visits enable that mothers and newborns are assessed in their own environment and education become more efficient for them.

\section{REFERENCES}

1. Açıkalın I. Sexual health mother health and family planning in Turkey. Ministry of Health, Mother-Child Health/Family Planning General Directorate 2007. http://www.tr.net/saglik/cinsel_saglik_turkiye_aile_planlamasi.sht ml (accessed 25 May 2007).

2. Goodrum LA. Maternal mortality: Strategies in prevention and care. Clinical Review Article. $2001 . \quad$ http://www.turnerwhite.com/pdf/hp_jan01_fetal.pdf (accessed 12 August 2007).

3. The Harriet and Robert Heilbrunn Department of Population and Family Health. Reproductive health module maternal mortality, Section V. 2007. http://www.columbia.edu/itc/hs/pubhealth/modules/reproductive Health/mortality.html (accessed 25 May 2007).

4. World Health Organization Departments of Reproductive Health and Research, Maternal Mortality in 2000, Geneva 2004. http://www.who.int/reproductive-

Health/publications/maternal mortality 2000/mme.pdf (accessed 25 May 2007).

5. Family Health International (FHI). Reproductive health, better postpartum care saves lives 2007. http://www.fhi.org/en/RH/Pubs/Network/v17 4/postpartum.htm (accessed 10 July 2007).

6. Hacettepe University Institute of Population Studies (HUNEE), ICON-INSTITUT Public Sector GmbH ve BNB Consultation. National Maternal Mortatility Study 2005. The Ministry of Health Maternal \& Child Health and Family Planning General Directorate and European Comission Turkish Delegation, Ankara, 2006. 
7. Koc I, Yuksel I, Eryurt MA. Infant and child mortality, Turkey Demographic and Health Survey TDHS-2008, Part 9, Hacettepe University Institute of Population, The Ministry of Health Maternal Child health General Directorate, Ministry of state planning organisation, TUBITAK, Ankara, 2009.

8. The Ministry of Health of Turkey. The instructions for carrying out health services Prime Ministry BAsic Health Services General Directorate, Ankara, 2001.

9. Ergöçmen BA, Tezcan S, Çağatay P. Reproductive Health: 2008 Turkey Demographic and Health Survey TDHS-2008 Part 10, Hacettepe University Institute of Population Studies, Ankara, Turkey, 2009.

10. Akın A, Özvarış ŞB. Utilization from childbirth and postpartum services in Turkey. 2002 http://www.huksam.hacettepe.edu.tr/Turkce/SayfaDosya/turkiyed e dogum sonrasi.pdf (accessed 10 March 2009).

11. Quinlivan JA, Box H, Evans SF. Postnatal home visits in teenage mothers: a randomized controlled trial. Lancet 2003;361:893-900

12. Escobar J, Braveman PA, Ackerson L et al A randomized comparison of home visits and hospital based group fallow up visits after early postpartum discharge, Pediatrics 2001;108(3):719-727.

13. Resmi Gazete. Turkiye Cumhuriyeti Resmi Gazete The Turkish Republic Official Gazete. 1996. Kanun [Law] No: 22805 (accessed 9 January 2007).

14. Sogukpinar N, Saydam BK, Bozkurt OD, Ozturk H, Pelik A. Past and present Midwifery education in Turkey. Midwifery 2007;23(4):43342

15. Gozum S, Kilic D. Health problems related to early discharge of Turkish women. Midwifery 2005; 21:371-378

16. Sullivan R, Magarick R, Berghthold G, Blouse A, McIntosh N, Sahin NN. Techniques of effective presentation, Skills of education for guideline of medical lecturers. Özvarıs SB (translation ed) Publishing of Hacettepe Public Health Foundation, Issue Number: 99/14. Ankara, 1999.

17. Yıldız A. Overview of adult education research in Turkey. Ankara University, Journal of Faculty of Educational Sciences 2004;37 (1):78-97

18. Gölbası Z, Early postpartum discharge home care services and nursing. Cumhuriyet University Journal of Nursing High School 2003;7

(2):15-22 http://www.cumhuriyet.edu.tr/edergi/makale/626.pdf $\quad$ (accessed 10 May 2007)

19. Bodur S, Tas F, Cevik E, Kurşun Ş. Contribution of midwive and nurses to Primiparous mothers knowledge. Journal of Ataturk University Nursing High School 2003;3:10-18

20. Keeling DI, Price PE, Jones E\&Harding KG. Social support: Some pragmatic implications for health care professionals. Journal of Advanced Nursing 1996;23:76-81

21. Brown SG, Johnson BT. Enhancing early discharge with home follow-up: A pilot project, JOGNN 1998;27(1):33-38

22. Bryar RM. Theory for Midwifery. Practica 1995;127-164

23. Jansson P. Early postpartum discharge, AJ N 1985;547-550

24. Willıams, LR, Cooper MK. Nurse-managed postpartum home care, JOGNN 1992;22(1):25-31

25. Malnory M. Mother-Infant home care drives quality in a managed care environment, J Nursing Care Quality 1997;11(4):9-26
26. Vittoz JP, Labarere J, Castell M, Durand M, Pons JC. Effect of training program for maternal ward professionals on duration of breastfeeding. Birth 2004;31(4):302-307

27. Balkaya NA. Care needs of mothers in postpartum period and the role of the midwife and nurse. Journal of Cumhuriyet University Nursing High School 2002;62:42-49 http://www.cumhuriyet.edu.tr/edergi/makale/614.pdf (accessed 11 March 2007).

28. Reeder S, Martin LL, Koniak-Griffin D. Maternity Nursing. Eighteenth Edition, Philadelphia, Lippincot Company 1997;p:636690 


\section{Funding}

This study was supported by grants from European Commission and Reproductive Health Program of Turkey as Scientific Research Project (Project no: DELTUR/2005/111450). 